\title{
RESEARCH
}

Open Access

\section{Job satisfaction among pharmacy professionals working in public hospitals and its associated factors, eastern Ethiopia}

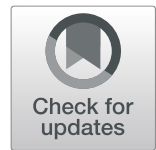

Yohanes Ayele ${ }^{1 *}$, Behailu Hawulte ${ }^{2}$, Tilayie Feto ${ }^{3}$, G. Vijai Basker $^{1}$ and Yadeta Dessie Bacha ${ }^{2}$

\begin{abstract}
Background: Poor job satisfaction has been associated with less productivity and high staff turnover. Various factors are thought to contribute for job dissatisfaction among pharmacy professionals and very limited studies have been conducted in eastern part of Ethiopia. Therefore, the current study was aimed to assess the level of job satisfaction among pharmacy professionals and its predictors.

Methods: A cross-sectional study was conducted among 232 pharmacy professionals to assess level of job satisfaction in public hospitals located in the eastern Ethiopia. The data were collected using self- administered semi-structured questionnaires. Data were entered into Epi-Data version 3.1 and exported to STATA version 14.2 for analysis. Associations between the dependent and independent variables were assessed by multivariate analysis using an Adjusted Odds Ratio (AOR) at a 95\% confidence interval (Cl) and p-value less than 0.05 was considered as significant.
\end{abstract}

Results: A total 220 questionnaires were found complete and included in the analysis. The mean age of participants was $27.6(\mathrm{SD} \pm 4.1)$. More than half of the respondents (55.4\%) had a bachelor degree and the majority (86.4\%) were working less than $40 \mathrm{~h}$ per week, mostly in dispensing units (75.4\%). About one third of the participants $(32.7,95 \% \mathrm{Cl} ; 26.8-39.2)$ were found to be satisfied with their job. Age category of 20 to 25 years in reference to age greater than 30 years $(\mathrm{AOR}=3.5,95 \% \mathrm{Cl} ; 1.1-9.7)$, holding a bachelor degree in reference to having diploma ( $A O R=4.2,95 \% \mathrm{Cl}$; 1.8-10.00), working for more than $40 \mathrm{~h}$ per week ( $\mathrm{AOR}=6.2,95 \% \mathrm{Cl}, 2.4-16)$, and working in dispensing units ( $\mathrm{AOR}=2.4,95 \% \mathrm{Cl} ; 1.1-5.5)$ were found to have strong association with job dissatisfaction.

Conclusion: In this study, the job satisfaction levels of pharmacy professionals were found to be very low. The age category of 20 to 25 , holding a bachelor degree, working for more than $40 \mathrm{~h}$ per week, and working in dispensing unit were found to be strong predictors of job dissatisfaction. Hence, pharmacy directors and hospital administrators should work to reduce unnecessary workload on the staffs and create good working climate.

Keywords: Pharmacy professionals, Job satisfaction, Eastern Ethiopia

\footnotetext{
* Correspondence: yohanesayele@ymail.com

'Department of Clinical Pharmacy, School of pharmacy, College of Health and Medical Sciences, Haramaya University, Harar, Ethiopia

Full list of author information is available at the end of the article
}

(C) The Author(s). 2020 Open Access This article is licensed under a Creative Commons Attribution 4.0 International License, which permits use, sharing, adaptation, distribution and reproduction in any medium or format, as long as you give appropriate credit to the original author(s) and the source, provide a link to the Creative Commons licence, and indicate if changes were made. The images or other third party material in this article are included in the article's Creative Commons licence, unless indicated otherwise in a credit line to the material. If material is not included in the article's Creative Commons licence and your intended use is not permitted by statutory regulation or exceeds the permitted use, you will need to obtain permission directly from the copyright holder. To view a copy of this licence, visit http://creativecommons.org/licenses/by/4.0/. The Creative Commons Public Domain Dedication waiver (http://creativecommons.org/publicdomain/zero/1.0/) applies to the data made available in this article, unless otherwise stated in a credit line to the data. 


\section{Introduction}

The services delivered by the hospital pharmacy unit are a vital component of an institutional health care system. Medication dispensing and drug distribution, compounding, medication utilization review, adverse drug reaction monitoring, drug information service, participating in drug and therapeutics committee are some of the services delivered by this unit [1]. Furthermore, in the past few decades, there has been a major shift in paradigm of pharmacy practice embracing the concept of clinical pharmacy which is intended to increase the involvement of pharmacy personnel in direct patient care $[2,3]$.

According to Avedis Donabedian, the health care quality can be measured through measuring the structure, process and outcome of health care system [4]. From the process aspect, one of the quality service indicators that have been widely used is the level of professionals' job satisfaction. By the same token, determining the job satisfaction level of the pharmacy professionals is expected to give insight in to the quality of pharmaceutical service $[5,6]$.

The key component of appropriate human resource management is keeping workers motivated which is highly dependent on their level of satisfaction. Job satisfaction is not only related to productivity but also the overall quality of life of the professionals [7]. Studies have demonstrated the importance of job satisfaction to an organization in terms of its positive relationship with individual performance, productivity, employee relations, physical and mental health and life satisfaction $[8,9]$. On the other hand, poor job satisfaction has been associated with less productivity and high staff turnover [1012].

Various factors are reported to affect job satisfaction of professionals which generally are grouped as intrinsic and extrinsic factors. The intrinsic factor included achievement, recognition and responsibility whereas extrinsic factors are interpersonal relations, working environment, salary among others [13-15]. Similarly, job satisfaction of pharmacists is reported to be affected by many factors including work environment and professional interaction, salary, governmental policies, promotion opportunities $[8,16-20]$. Hence, identifying the influencing factors and maintaining job satisfaction in the work place will have a significant effect on staff retention and providing appropriate patient care.

In Ethiopia, hospital pharmacy professionals are a key component of the health care system. The Pharmacy professionals in these settings are expected to provide dispensing services in four departments; outpatient, inpatient department, antiretroviral therapy, and emergency unit. The inventory and logistics management, and clinical pharmacy services which is recently introduced model of pharmacy practice is another practice area for Ethiopian hospital pharmacists [21]. Regardless of the much-needed service of these professionals, the country suffers from serious pharmacy workforce scarcity, a study reporting pharmacist density of 2.38 per 100,000 populations which is the smallest number compared to other African countries [22].

Moreover, in Ethiopia, there is growing need for pharmacy professionals as the health care institutions continue to expand and the government looks for full implementation of clinical pharmacy service [21, 23]. To make things worse, reports indicate poor job satisfaction among pharmacy professionals amid inadequate compensation, inadequate management systems, heavy workloads, and lack of technical support among others $[22,24]$.

As far as our knowledge goes, there are no sufficient and effective studies highlighting the pharmacy professionals' job satisfaction level in public hospitals, particularly in the eastern part of the country. We believe that measuring the level of job satisfaction of pharmacy professionals would be important as it can generate information that could help employers and organizations to change their approach in the management of pharmacy professionals. Therefore, the aim of this study was to assess the level of job satisfaction and associated factors among pharmacy professionals in Eastern part of Ethiopia.

\section{Methods}

\section{Study setting and period}

A cross-sectional study was conducted at public hospitals in Eastern Ethiopia from September to December, 2018 to assess pharmacy professionals' job satisfaction and associated factors. Three regional states are located in eastern part of Ethiopia; Harar, part of Oromia, and Ethiopian Somali region. This study was conducted in western and eastern Hararghe zone of Oromia region, Harar region, Diredawa administrative city and Fafan Zone of the Ethiopian Somali region. In the study area, there were 13 public hospitals; two specialized hospitals, eight general hospitals, and three primary hospitals.

\section{Study population}

All health care professionals working in study hospitals were the source population. All pharmacy professionals working in the study hospitals during the study period were included in the study. Newly recruited pharmacy professionals who worked in the respective hospitals for less than 3 months were excluded from the study.

\section{Sample size and sampling technique}

The number of pharmacy professionals participated in the job satisfaction survey was determined using the 
single proportion formula. The sample size was determined assuming $60.8 \%$ prevalence of pharmacy professional job satisfaction [25], sampling error of 5 and $95 \%$ confidence interval. Hence, the sample size calculated was 366. Since the total (source) population in the current study were less than 10,000 , we used the population correction formula [26].

$$
n f=\frac{n}{1+\left(\frac{n}{N}\right)}
$$

Where $\mathrm{nf}=$ final sample, $\mathrm{N}=$ total number of pharmacy professionals working in the hospitals included in the study during data collection period which was equal to 500 according to report from hospitals administration.

Accordingly, a total of 232 sample size was considered after adding $10 \%$ non-response rate. The participants included in the study were sampled from all 12 hospitals. The final sample was distributed throughout the study hospitals proportionally considering the number of pharmacy professionals working in each hospital during the data collection period to ensure the representativeness of the sample.

\section{Data collection tools and procedures}

A self-administered semi-structured questionnaire was used to assess the level of pharmacy professionals' job satisfaction. The questionnaire was adapted from previous similar study [27]. The tool contained three sections; socio-demographic characteristics, pharmacy professionals' characteristics, and the level of pharmacy professional job satisfaction. The later section had three categories of questions: items on working environment designed to assess satisfaction with physical working environment comprising 11 questions; items on professional interactions designed to assess inter-professional interaction with fellow pharmacy professionals, nurses and physicians comprising of seven questions and items on incentive and recognition designed to asses satisfaction with monetary compensation and professional recognition comprising of seven questions. A five-point Likert scale, value ranging from 1 (strongly disagree) to 5 (strongly agree), was used to rate the questions. Pretest was conducted and necessary modification was done. The content of questions was modified specifically vague and complex statements were corrected to improve understandability. Additionally, instruction for respondents was revised based on the pre-test finding.

\section{Data processing and analysis}

The coded data were entered into Epi-Data version 3.1 after checking for completeness and exported to STATA version 14.2 for analysis. Data were described using proportion, mean and standard deviation. After checking for normality of data, we used mean score to determine magnitude of overall job satisfaction [28, 29]. Consequently, respondents with an average score of less than mean value, were classified as dissatisfied, and those with an average score of mean value and above were considered as satisfied. Bivariate and multivariable analyses were done to identify the factors associated with providers' level of satisfaction. The variables with a $p$-value of less than 0.25 in the bivariate analysis were included in the multivariable analysis to account for all important variables [30, 31]. Associations between the dependent and independent variables were assessed using adjusted odds ratio (AOR) at a 95\% confidence interval (CI) and the $p$-value less than 0.05 was considered as significant.

\section{Results}

Socio-demographic characteristics of participants

A total of 232 questionnaires were distributed and overall 220 participants filled the questionnaires completely and therefore used for the data analysis. As can be seen

Table 1 Socio-demographic characteristics of pharmacy professional assessed for job satisfaction in public hospitals in Eastern Ethiopia, $2017(n=220)$

\begin{tabular}{ll}
\hline Variables & Number (\%) \\
\hline Sex & $134(60.9)$ \\
Male & $86(39.1)$ \\
Female & \\
Age & $78(35.4)$ \\
$20-25$ & $108(49.1)$ \\
$26-30$ & $34(15.5)$ \\
above 30 & \\
Marital status & $130(59.1)$ \\
Single & $86(39.1)$ \\
Married & $4(1.8)$ \\
Divorced & \\
Current religion & $86(39.1)$ \\
Muslim & $94(42.7)$ \\
Orthodox & $24(10.9)$ \\
Protestant & $2(0.9)$ \\
Catholic & $14(6.4)$ \\
Others & \\
Monthly salary (ETB) & \\
Less than 2500 & $20(9.1)$ \\
2501-5000 & $260(90.9)$ \\
Other source of income & $110(50.0)$ \\
Yes & $84(38.2)$ \\
No & \\
\hline ETB-Ethiopian Birr, based on the Ethiopian civil servant monthly salary scale
\end{tabular}


from Table 1, considerable portion (60.9\%) of the participants were male. Considering the age of professionals, the mean age of the participants was 27.6(SD +4.1$)$. More than half of the professionals (59.1\%) were single. Regarding monthly income, exactly half of the participants were receiving the salary of ranging from 2501 to 5000 Ethiopian birr (ETB) and most of the participants had no other source of income.

\section{Pharmacy professionals' characteristics}

As Table 2 shows, more than half of the respondents (55.4\%) had a bachelor degree in pharmacy during the

Table 2 Pharmacy professionals' characteristics assessed for job satisfaction in public hospitals in Eastern Ethiopia, $2018(n=220)$

\begin{tabular}{ll}
\hline Variables & Number (\%) \\
\hline Qualification & \\
Diploma in pharmacy & $98(44.6)$ \\
Degree in pharmacy & $122(55.4)$ \\
Service year/s & \\
$<2$ & $60(27.3)$ \\
$2-4$ & $88(40.0)$ \\
$>4$ & $72(32.7)$
\end{tabular}

Working hours per week ${ }^{\mathrm{a}}$

$40 \mathrm{~h}$ and less

more than $40 \mathrm{~h}$

$30(13.6)$

Current working unit

Dispensing

$166(75.4)$

Inpatient Ward

$28(12.7)$

Inventory and drug supply control

$10(4.6)$

Administrative activities

$16(7.3)$

Dispensing unit $(n=166)$

Outpatient unit

$94(56.6)$

Inpatient unit

$40(24.1)$

Emergency Drugs unit

$12(7.2)$

Antiretroviral Drugs unity

$20(12.1)$

Technical support or supervision

No

$124(56.4)$

Yes

Measures to increase job satisfaction ${ }^{b}$

More knowledge or updates or training

$96(43.6)$

More incentives for professionals

$158(71.8)$

Better facility infrastructure

$114(51.8)$

106 (48.2)

Less workload

$90(40.9)$

More support from supervisor

$70(32.4)$

More quality supplies or stock

$66(30.3)$

More autonomy or independence

38 (17.3)

aProfessionals are expected to serve $40 \mathrm{~h}$ per week (five working days), ${ }^{\mathbf{b}}$ the sum does not give $100 \%$ data collection period while the remaining held college diploma. The average $( \pm S D)$ service years of providers was $3.7( \pm 2.9)$ years and the average $( \pm \mathrm{SD})$ working hours of the providers was $41.1( \pm 5.2)$ hours per week. As to the professionals' current working unit, a large proportion of participants $(75.4 \%)$ were working in different dispensing unit of hospitals. It was noted that only $12.7 \%$ professionals were working in the ward to deliver clinical pharmacy services. Regarding technical support or supervision participants received during previous one-year period, slightly more than half of the participants (56.4\%) reported lack of technical support or supervision. With relation to the professionals' opinion on the measure required to increase job satisfaction, the participants mentioned the need for more knowledge or updates or training 158 (71.8\%), more incentives 114 (51.8\%), and better facility infrastructure 106 (48.2\%).

\section{Job satisfaction among pharmacy professionals}

The job satisfactions of the professionals were assessed using 25 questions which were grouped in to three categories; working environment, interpersonal interactions, and incentive and recognition. We calculated both the overall satisfaction level and satisfaction level within each category. Table 3 shows response of all participants for each question. Figure 1 depicts the job satisfaction level of the participants summarized in three categories. In this study, only about one third of the participants (32.7, 95\% CI; 26.8-39.2) were found to be satisfied with their job. The mean $( \pm \mathrm{SD})$ satisfaction level calculated out 5 was $2.8( \pm 0.7)$.

In regard to satisfaction level of in each category, just under one half of the participants (48.2\%) were satisfied with the physical working environment. The figure drops further to less than one fifth $(17.3 \%)$ for professional interaction. Although it was not comparable with satisfaction seen on the professional interaction, the satisfaction level seen among professionals on the incentive and recognition related issues was low, only one third $(36.4 \%)$ of the respondents reported satisfaction.

\section{Determinants of job satisfaction among pharmacy professionals}

In this study, age, qualification level, working hours and current working unit of participants were found to be strong predictors of job satisfaction for pharmacy professionals. In relation to age, participants who were in the age range of $20-25$ years were found to be 3.5 times $(\mathrm{AOR}=3.5,95 \% \mathrm{CI} ; 1.1-9.7)$ more likely to be dissatisfied compared with professionals who were above 30 years.

Another determinant of job satisfaction seen in this study was level of qualification of participants. According to our finding, pharmacy professionals who held a 
Table 3 Proportions of pharmacy professionals' response to job satisfaction questions in Easter Ethiopia, 2018 ( $n=220)$

\begin{tabular}{|c|c|c|c|c|c|}
\hline Questions & $\begin{array}{l}\text { Strongly disagree } \\
\mathrm{n}(\%)\end{array}$ & $\begin{array}{l}\text { Disagree } \mathrm{n} \\
(\%)\end{array}$ & $\begin{array}{l}\text { Neutral } \mathrm{n} \\
(\%)\end{array}$ & $\begin{array}{l}\text { Agree } n \\
(\%)\end{array}$ & $\begin{array}{l}\text { Strongly agree } \\
\mathrm{n}(\%)\end{array}$ \\
\hline \multicolumn{6}{|l|}{ Working environment } \\
\hline The opportunity for promotion in this hospital is good. & $20(9.1)$ & $52(23.6)$ & $58(26.4)$ & $74(33.6)$ & $16(7.3)$ \\
\hline I am proud to be working for this hospital. & $16(7.3)$ & $30(13.6)$ & $34(15.5)$ & $\begin{array}{l}112 \\
(50.9)\end{array}$ & $28(12.7)$ \\
\hline Rules and regulation in this hospital are applied equally. & $32(14.6)$ & $38(17.3)$ & $78(35.5)$ & $56(25.5)$ & $6(7.3)$ \\
\hline My supervisor gives serious consideration to employee complaints. & $20(9.1)$ & $34(15.4)$ & $80(36.4)$ & $78(35.5)$ & $8(3.6)$ \\
\hline Employees have a sufficient amount of freedom to decide how they do their work. & $22(10.0)$ & $38(17.3)$ & $74(33.6)$ & $74(33.6)$ & $12(5.5)$ \\
\hline Staffing is adequate; enough employees are hired to cover the workload in the pharmacy & $32(14.6)$ & $80(36.4)$ & $36(16.4)$ & $54(24.5)$ & $18(8.1)$ \\
\hline My supervisor is capable of providing proper guidance. & $24(10.9)$ & $36(16.4)$ & $80(36.4)$ & $74(33.6)$ & $6(2.7)$ \\
\hline $\begin{array}{l}\text { The hospital management respects and treats pharmacy professionals similar to other health } \\
\text { professionals in the hospital. }\end{array}$ & $22(10.0)$ & $56(25.5)$ & $46(20.9)$ & $72(32.7)$ & $24(10.9)$ \\
\hline Scheduling of work hours takes into account individual employee needs. & $16(7.3)$ & $44(20.0)$ & $68(30.9)$ & $80(36.4)$ & $12(5.4)$ \\
\hline I am comfortable with my work load. & $34(15.4)$ & $74(33.6)$ & $38(17.3)$ & $58(26.4)$ & $16(7.3)$ \\
\hline There is suitable working environment (lighting, air condition, toilet facilities, and rest room) & $56(25.5)$ & $58(26.4)$ & $44(20.0)$ & $50(22.7)$ & $12(5.4)$ \\
\hline \multicolumn{6}{|l|}{ Professional interaction } \\
\hline Physicians consult me on professional matters. & $16(7.3)$ & $22(10.0)$ & $44(20.0)$ & $92(41.8)$ & $46(20.9)$ \\
\hline Physicians cooperate when I communicate professional matters with them. & $14(6.4)$ & $20(9.1)$ & $42(19.1)$ & $\begin{array}{l}120 \\
(54.5)\end{array}$ & $24(10.9)$ \\
\hline My fellow employee pharmacy professionals treat me with professional respect. & $14(6.3)$ & $16(7.3)$ & $42(19.1)$ & $90(40.9)$ & $58(26.4)$ \\
\hline My fellow employees are friendly. & $6(2.8)$ & $28(12.8)$ & $24(11.0)$ & $94(43.1)$ & $66(30.3)$ \\
\hline Nurses cooperate when I communicate professional matters with them. & $8(3.6)$ & $14(6.4)$ & $38(17.4)$ & $\begin{array}{l}130 \\
(59.0)\end{array}$ & $30(13.6)$ \\
\hline Nurses often initiate consultations with me on professional matters. & $10(4.6)$ & $28(12.7)$ & $46(20.9)$ & $\begin{array}{l}112 \\
(50.9)\end{array}$ & $24(10.9)$ \\
\hline I am satisfied with the working relationships I have with other staffs. & $18(8.2)$ & $16(7.2)$ & $32(14.6)$ & $\begin{array}{l}102 \\
(46.4)\end{array}$ & $52(23.6)$ \\
\hline \multicolumn{6}{|l|}{ Incentive and recognition } \\
\hline The monetary rewards I receive from my work are appropriate. & $52(23.8)$ & $52(23.9)$ & $58(26.6)$ & $54(24.8)$ & $2(0.9)$ \\
\hline My salary is fair considering the service I give. & $52(23.6)$ & $78(35.5)$ & $34(15.5)$ & $50(22.7)$ & $6(2.7)$ \\
\hline I receive adequate incentive for my wok. & $60(27.3)$ & $70(31.8)$ & $30(13.6)$ & $42(19.1)$ & $18(8.2)$ \\
\hline My talents are fully utilized on my job. & $34(15.5)$ & $26(11.8)$ & $76(34.5)$ & $70(31.8)$ & $14(6.4)$ \\
\hline I am willing to continue the current job in future too. & $24(10.9)$ & $26(11.8)$ & $36(16.4)$ & $96(43.6)$ & $38(17.3)$ \\
\hline I often leave work with a feeling that I'm doing something which I enjoy. & $16(7.3)$ & $22(10.0)$ & $40(18.2)$ & $\begin{array}{l}122 \\
(55.4)\end{array}$ & $20(9.1)$ \\
\hline $\begin{array}{l}\text { Knowing what I know now, if I had to decide all over again, I would still choose pharmacy as } \\
\text { my profession. }\end{array}$ & $18(8.2)$ & $22(10.0)$ & $30(13.6)$ & $96(43.6)$ & $54(24.6)$ \\
\hline
\end{tabular}

bachelor degree were found to be 4.2 times $(\mathrm{AOR}=4.2$, 95\% CI;1.8-10.00) more dissatisfied in reference to diploma holders. In the present study, working hours per week were also found to have significant association with job satisfaction of participants. As it is shown in Table 4, respondents who were working for more than $40 \mathrm{~h}$ per week were 6.2 times $(\mathrm{AOR}=6.2,95 \% \mathrm{CI} ; 2.4-16)$ more dissatisfied in reference with participants who were engaged $40 \mathrm{~h}$ or less per week. Finally, working in dispensing units was found to be a source of dissatisfaction. It was found that pharmacy professionals working in dispensing units were 2.4 times $(\mathrm{AOR}=2.4$, 95\% $\mathrm{CI}$; $1.1-$ 5.5) dissatisfied in reference to respondents who were working in other units.

\section{Discussion}

This study was conducted to assess overall job satisfaction and its determinants among pharmacy professionals working in public hospitals in eastern Ethiopia. In our study only $32.7 \%$ of the professional were satisfied with their job. The mean satisfaction level of was $2.8( \pm 0.7)$. Factors such as being at age 20 to 25 years, level of qualification, working hours per week, and current working unit were strongly associated with respondents' job satisfaction.

It is obvious that hospital pharmacy services suffer from lack of quality in Ethiopia [24, 32]. Job satisfaction is a key factor affecting professional motivation and productivity since satisfied workers are in better position 
to deliver the service to the expected standard. In the present study, the job satisfactions of pharmacy professionals working in public hospitals were found to be very low, only about one in three of participants reporting satisfaction (32.7, 95\% CI; 26.8-39.2), the mean satisfaction $2.8( \pm 0.7)$ measured out of five. This finding is consistent with research conducted in Gondar university hospital in which the mean satisfaction was 2.7 [24], and report from Addis Ababa, 3.0 \pm 1.1 (mean \pm SD) [22] However, the finding is lower than Australian study 3.6 $+/-0.7$ [29], and a report by Mohamed mansor manan et al., 52\% [33]. It is also significantly lower than a study conducted to assess job satisfaction among health care professionals in the university hospital of Gondar (54\%) [34] and Jimma, Ethiopia (41.4\%) [35]. Consequently, it is very important for the hospital management to look deep in to the case and take appropriate measures.

Studies have identified the number of determinants for job satisfaction, including demographic characteristics such as age, gender, monthly salary, education among others though the results were inconclusive [36-39]. One of the demographic variables often reported to have an association to job satisfaction was age. Age in general is reported to have U-shaped association with job satisfaction [16], the professionals having good satisfaction in the beginning of their career which drops in their mid, only to get better at the end of their career. There are also sizeable reports indicating better satisfaction in both ends of professionals' career [33, 40-42].

In the present study, participants who were between the ages of 20 to 25 were more dissatisfied with their job compared to older fellow professionals $(\mathrm{AOR}=3.5$, 95\% CI; 1.1-9.7). This finding is in agreement with study conducted in Malaysia which reported better satisfaction in the age group of 35-45 years compared to younger pharmacists [33] and elsewhere [22, 36, 40, 41, 43, 44]. The possible explanation for this finding is a high expectation of new employee and unmet need leading to dissatisfaction [41, 43]. It is also good to consider the methodological variation and the effect of confounding variables while comparing these results.

Generally, studies assessed the effect of qualification level on one's job satisfaction is indecisive. There is strong evidence implying that people with higher level of education have better levels of job satisfaction because of better opportunities that come along [45]. This might stand true for pharmacy professional as well particularly for those who achieve higher education than Bachelor degree. In addition, sense of achievement through attaining higher degree is also thought to be a possible source of satisfaction [18, 42, 43, 46]. In Ethiopia, three ladders of education level are expected for pharmacy professionals working in hospital pharmacy; college certificate or diploma, Bachelor of pharmacy and masters of Science in pharmacy. Coincidentally, all the pharmacy professionals who participated in this study had either diploma or degree. In the present study, pharmacists with degree qualification were more likely to be dissatisfied compared to professionals having diploma $(\mathrm{AOR}=$ $4.2,95 \% \mathrm{CI} ; 1.8-10.0)$. Decreased satisfaction seen in this setting might be due to perceived lack of their skill being fully utilized [36, 47-49].

Work load can be an important source of job dissatisfaction. In our study, we found professionals who were working for more than $40 \mathrm{~h}$ per week which is minimum hours civil servants are expected to serve per week in

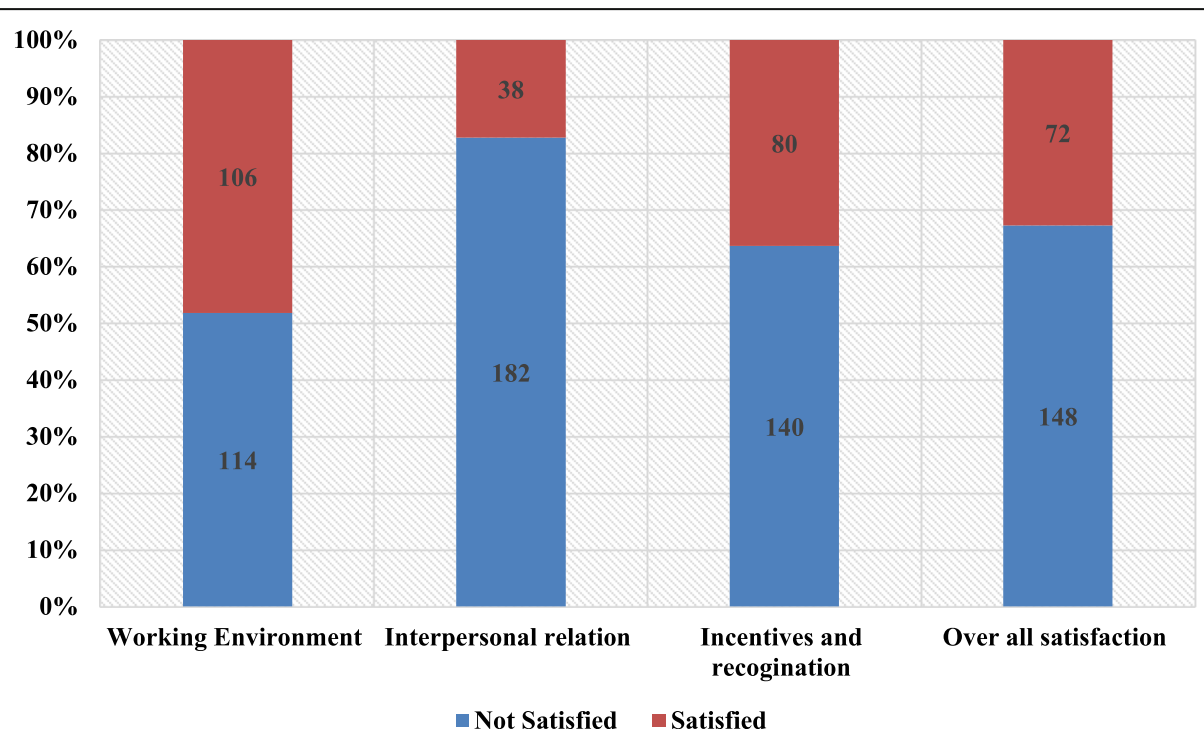

Fig. 1 Level of overall job satisfaction and satisfaction on working environment, interpersonal relations, and incentive and recognition, among Pharmacy professionals in Easter Ethiopia, $2018(n=220)$ 
Table 4 Determinants of job satisfaction among pharmacy professionals in Easter Ethiopia, $2018(n=220)$

\begin{tabular}{|c|c|c|c|c|c|c|}
\hline \multirow[t]{2}{*}{ Variables } & & \multicolumn{2}{|l|}{ Satisfaction } & \multirow[t]{2}{*}{ COR $(95 \% \mathrm{Cl})$} & \multirow[t]{2}{*}{ AOR (95\% Cl) } & \multirow{2}{*}{$\begin{array}{l}\boldsymbol{P} \\
\text { value }\end{array}$} \\
\hline & & No $(\boldsymbol{n}=148)$ n (\%) & Yes $(\boldsymbol{n}=72) \mathrm{n}(\%)$ & & & \\
\hline \multirow[t]{2}{*}{ Sex } & Female & $58(39.2)$ & $28(38.9)$ & 1 & 1 & 0.741 \\
\hline & Male & $90(60.8)$ & $44(61.1)$ & $1.01(0.6-1.8)$ & $0.9(0.4-1.7)$ & \\
\hline \multirow[t]{3}{*}{ Age } & $>30$ & $26(17.6)$ & $8(11.1)$ & 1 & 1 & \\
\hline & $26-30$ & $78(52.7)$ & $30(41.7)$ & $1.3(0.5-3.1)$ & $1.3(0.5-3.3)$ & 0.736 \\
\hline & $20-25$ & $44(29.7)$ & $34(47.2)$ & $2.5(1.01-6.2)$ & $3.5(1.1-9.7)$ & 0.041 \\
\hline \multirow[t]{3}{*}{ Monthly salary } & $<2500$ & $21(14.2)$ & $5(7.0)$ & 1 & 1 & \\
\hline & $2500-5000$ & $68(45.9)$ & $42(58.3)$ & $2.6(0.9-7.4)$ & $1.6(0.5-5.1)$ & 0.375 \\
\hline & $>5000$ & 59 (39.9) & $25(34.7)$ & $1.8(0.6-5.2)$ & $0.9(0.2-3.4)$ & 0.885 \\
\hline \multirow[t]{2}{*}{ Qualification } & Diploma & $72(48.7)$ & $26(36.1)$ & 1 & 1 & 0.002 \\
\hline & Degree & 76 (51.3) & $46(63.9)$ & $1.7(0.9-3.0)$ & $4.2(1.8-10.0)$ & \\
\hline \multirow[t]{3}{*}{ Service years } & $<2$ & $36(24.3)$ & $24(33.3)$ & 1 & 1 & \\
\hline & $2-4$ & $62(41.9)$ & $26(36.1)$ & $0.6(0.3-1.3)$ & $1.4(0.6-3.3)$ & 0.430 \\
\hline & $>4$ & $50(33.8)$ & $22(30.6)$ & $0.7(0.3-1.4)$ & $1.1(0.4-3.2)$ & 0.690 \\
\hline \multirow[t]{2}{*}{ Working hours per week } & $\leq 40 \mathrm{~h}$ & $136(91.9)$ & $54(75.0)$ & 1 & 1 & 0.000 \\
\hline & $>40 \mathrm{~h}$ & $12(8.1)$ & $18(25.0)$ & $3.8(1.7-8.4)$ & $6.2(2.4-16.1)$ & \\
\hline \multirow[t]{2}{*}{ Current working unit } & Non-dispensing units ${ }^{\mathbf{a}}$ & $40(27.0)$ & $14(19.3)$ & 1 & 1 & 0.039 \\
\hline & Dispensing units & $108(73.0)$ & $58(80.6)$ & $1.5(0.8-3.1)$ & $2.4(1.1-5.5)$ & \\
\hline \multirow[t]{2}{*}{ Technical support or supervision } & No & $82(55.4)$ & $42(58.3)$ & 1 & 1 & 0.970 \\
\hline & Yes & 66 (44.6) & $30(41.7)$ & $0.9(0.5-1.6)$ & $0.9(0.5-1.9)$ & \\
\hline
\end{tabular}

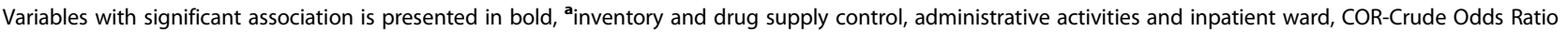

Ethiopia dissatisfied with their job. This is in line with other studies which reported long working hours as a source of discontent among pharmacy professionals [16, 50-52]. Hence, management of hospital particularly hospital pharmacy managers should distribute the activities in a way it does not create workload on the employee. Furthermore, management should ensure presence of adequate human resource to balance the work load. This can be achieved through recruiting new staffs and increasing efficiency and expanding pharmacy workforce at national level.

In Ethiopian health care system, pharmacy professionals play multiple role including working in ward, dispensing, inventory and logistics management and administration. In the present study, pharmacy professionals working in dispensing units were found to have less satisfaction level compared to professionals working in other units $(\mathrm{AOR}=2.4,95 \% \mathrm{CI} ; 1.1-5.5)$. There are studies indicating pharmacists' preference of clinical activities which thought to be more challenging over distributive functions [36, 41, 53]. However, given that the practice of clinical pharmacy is in its infancy stage in Ethiopia, the possible explanation to high dissatisfaction among pharmacy professionals working in dispensing units could be high work load and the less comfortable working environment [32, 34, 35, 54].
This research is not without limitation. Firstly, since it was cross-sectional study, we were not able to establish cause-effect relationship between factors that were reported to have strong association with job satisfaction. Secondly, this research was limited to pharmacy professionals working in public hospitals; hence it should be generalized cautiously. What is more it was assumed that the job satisfaction seen is due to job related activities while some personal factors such as socio-economic factors might have affected the reported satisfaction level. Finally, the data is also subjected to bias as it is self-reported.

\section{Conclusion}

In this study, the job satisfaction levels of pharmacy professionals were found to be very low. Regarding factors affecting job satisfaction, different factors were found to have association. From sociodemographic variables, age (category of 20 to 25), was found to be strong predictors of job dissatisfaction however, gender and other variables didn't have impact on job satisfaction. The professionals' qualification level and working condition were also found to have influence on job satisfaction; holding a bachelor degree, working for more than $40 \mathrm{~h}$ per week, and working in dispensing unit showing strong association with job dissatisfaction. Hence, pharmacy directors 
and hospital administrators should work to reduce unnecessary workload on the staffs and make the working environment more comfortable.

\section{Abbreviations}

AOR: Adjusted odds ratio; Cl: Confidence interval; SD: Standard Deviation

\section{Acknowledgements}

The authors are very grateful for the financial support given by Haramaya University to undertake this research. Our appreciation also goes to data collectors and pharmacy professionals who participated in the study. Finally, we would like to extend our deepest gratitude to hospital management for their cooperation during the data collection period.

\section{Authors' contribution}

All authors participated starting from the conception of the research idea to interpretation of the result and manuscript authorization. All authors have read and agreed to the final manuscript. The author(s) read and approved the final manuscript.

\section{Funding}

This research was conducted by financial support obtained from Haramaya University

\section{Availability of data and materials}

The data collection tools are attached as an additional supporting file. The datasets are available from the corresponding author on reasonable request.

\section{Ethics approval and consent to participate}

Ethical clearance was obtained from Haramaya University, Institutional Health Research Ethics Review Committee. Formal letter was submitted to director of study Hospitals. The data collectors explained objectives, benefit and risk of the study to obtain consent from study participants prior to distributing questionnaires. The parameters were coded to exclude showing names and no reference was made in oral or written reports that could link participants to the research.

\section{Consent for publication}

Not applicable since there are no individual details in our result.

\section{Competing interests}

The authors declare that they have no competing interest.

\section{Author details}

'Department of Clinical Pharmacy, School of pharmacy, College of Health and Medical Sciences, Haramaya University, Harar, Ethiopia. ${ }^{2}$ School of public health, College of Health and Medical Sciences, Haramaya University, Harar, Ethiopia. ${ }^{3}$ School of nursing and midwifery, College of Health and Medical Sciences, Haramaya University, Harar, Ethiopia.

\section{Received: 20 August 2019 Accepted: 8 April 2020}

\section{Published online: 11 May 2020}

\section{References}

1. American Society of Health-System Pharmacists. ASHP guidelines: minimum standard for pharmacies in hospitals. Am J Health Syst Pharm. 2013;70(18): 1619-30.

2. Al-Shagha WMS. The role of quality in pharmaceutical care management Manag Serv Qual. 2001;11(1):32-9.

3. Wiedenmayer K, Summers RS, Mackie CA, Gous AGS, Everard M. Developing pharmacy practice: a focus on patient care. World Health Organ Int Pharm Fed. 2005; Available from: https://www.fip.org/

.../DevelopingPharmacyPractice/DevelopingPharmacy.

4. Donabedian A. The quality of care. How can it be assessed? Jama. 1988; 260(12):1743-8

5. Best M, Neuhauser D. Avedis Donabedian: father of quality assurance and poet. Qual Saf Health Care. 2004:13(6):472-3.

6. Nau DP. Measuring pharmacy quality. J Am Pharm Assoc. 2009;49(2):154-63.

7. Schermerhorn JR, James JH, Obsorn RN. Organizational behavior. $7^{\text {th }}$ ed. New York: Wiley; 2002.
8. Bhatnagar K, Srivastava K. Job satisfaction in health-care organizations. Ind Psychiatry J. 2012;21(1):75-8

9. Borkowski N. Organizational behavior in health care. 2nd ed. Boston: Jones \& Bartlett; 2011.

10. Pathman DE, Konrad TR, Williams ES, Scheckler WE, Linzer M, Douglas J. Physician job satisfaction, dissatisfaction, and turnover. J Fam Pract. 2002; 51(7):593.

11. Boswell WR, Boudreau JW, Tichy J. The relationship between employee job change and job satisfaction: the honeymoon-hangover effect. J Appl Psychol. 2005;90(5):882-92.

12. Hawthorne N, Anderson C. The global pharmacy workforce: a systematic review of the literature. Hum Resour Health. 2009;7(1):48.

13. Gazioglu S, Tansel A. Job satisfaction in Britain: individual and job related factors. Appl Econ. 2006;38(10):1163-71.

14. Judge TA, Piccolo RF, Podsakoff NP, Shaw JC, Rich BL. The relationship between pay and job satisfaction: a meta-analysis of the literature. J Vocat Behav. 2010;77(2):157-67.

15. Lee R, Wilbur ER. Age, education, job tenure, salary, job characteristics, and job satisfaction: a multivariate analysis. Hum Relat. 1985;38(8):781-91.

16. Carvajal MJ, Popovici I. Gender, age, and pharmacists' job satisfaction. Pharm Pract. 2018;16(4):1396.

17. Carvajal MJ, Popovici I, Hardigan PC. Gender differences in the measurement of pharmacists' job satisfaction. Hum Resour Health. 2018; 16(1):33.

18. Cox ER, Fitzpatrick V. Pharmacists' job satisfaction and perceived utilization of skills. Am J Health Syst Pharm. 1999;56(17):1733-7.

19. Ahmad A, Patel I. Job satisfaction among Indian pharmacists. J Pharm Bioallied Sci. 2013;5(4):326.

20. Kuiper RL, Cowan DL, Pacitti R. Job satisfaction in hospital pharmacists. Am J Health Syst Pharm. 2011;68(2):115.

21. Bilal Al, Tilahun Z, Gebretekle GB, Ayalneh B, Hailemeskel B, Engidawork E. Current status, challenges and the way forward for clinical pharmacy service in Ethiopian public hospitals. BMC Health Serv Res. 2017;17(1):359.

22. Gebremedhin BG, Teferi GF. Assessment of pharmacists workforce in Ethiopia. Ethiop J Health Dev. 2013;27.

23. Henok GT, Ousam AA, Abebe BM, Akshaya SB. Challenges and opportunities of clinical pharmacy services in Ethiopia: a qualitative study from healthcare practitioners' perspective. Pharm Pract. 2018;16(1):1121.

24. Surur AS, Teni FS, Girmay G, Moges E, Tesfa M, Abraha M. Assessment of the structural and process aspects of pharmaceutical care at a university hospital in Ethiopia. J Pharm Bioallied Sci. 2015;7(2):97-102.

25. Ahmed SM, Tolera M, Angamo M. Assessment of job satisfaction among pharmacy professionals in Southwest Ethiopia. Int J Pharm Sci Res. 2013; 4(6):2351-8.

26. Israel GD. Determining sample size. Florida: University of Florida Cooperative Extension Service, Institute of Food and Agriculture Sciences, EDIS; 1992. Available from https://www.tarleton.edu.academicassessment.documents. Samplesize.

27. Kerschen AM, Armstrong EP, Hillman TN. Job satisfaction among staff, clinical, and integrated hospital pharmacists. J Pharm Pract. 2006;19(5):30612.

28. Sullivan GM, Artino AR. Analyzing and interpreting data from likert-type scales. J Grad Med Educ. 2013:5(4):541-2.

29. Norman G. Likert scales, levels of measurement and the "laws" of statistics. Adv Health Sci Educ Theory Pract. 2010;15(5):625-32.

30. Bendel RB, Afifi AA. Comparison of stopping rules in forward regression. J Am Stat Assoc. 1977:72:46-53.

31. Mickey J, Greenland S. A study of the impact of confounder-selection criteria on effect estimation. Am J Epidemiol. 1989:129:125-37.

32. Eshetu $\mathrm{E}$, Gedif T. Quality of pharmacy services in government hospitals in Addis Ababa, Ethiopia. Ethiopian Pharm J. 2011;29:108-20.

33. Manan MM, Azmi Y, Lim Z, Neoh CF, Khan TM, Ming LC. Predictors of job satisfaction amongst pharmacists in Malaysian public hospitals and healthcare clinics. J Pharm Pract Res. 2015:45:404-11.

34. Gedif G, Sisay Y, Alebel A, Belay YA. Level of job satisfaction and associated factors among health care professionals working at University of Gondar Referral Hospital, Northwest Ethiopia: a cross-sectional study. BMC Res Notes. 2018:11(1):824.

35. Yami A, Hamza L, Hassen A, Jira C, Sudhakar M. Job satisfaction and its determinants among health workers in Jimma university specialized hospital, Southwest Ethiopia. Ethiop J Health Sci. 2011;21(Suppl 1):19-27. 
36. Liu CS, White L. Key determinants of hospital pharmacy staff's job satisfaction. Res Soc Adm Pharm. 2011;7(1):51-63.

37. Seston E, Hassell K, Ferguson J, Hann M. Exploring the relationship between pharmacists' job satisfaction, intention to quit the profession, and actual quitting. Res Soc Adm Pharm. 2009;5(2):121-32.

38. Mott DA. Pharmacist job turnover, length of service, and reasons for leaving, 1983-1997. Am J Health Syst Pharm. 2000;57(10):975-84.

39. Chua GN, Yee LJ, Sim BA, Tan KH, Sin NK, Hassali MA, et al. Job satisfaction, organisation commitment and retention in the public workforce: a survey among pharmacists in Malaysia. Int J Pharm Pract. 2014;22(4):265-74.

40. Hardigan PC, Sangasubana N. A latent class analysis of job satisfaction and turnover among practicing pharmacists. Res Soc Adm Pharm. 2010;6(1):328

41. Lau WM, Pang J, Chui W. Job satisfaction and the association with involvement in clinical activities among hospital pharmacists in Hong Kong. Int J Pharm Pract. 2011;19(4):253-63.

42. Sansgiry SS, Ngo C. Factors affecting job satisfaction among hospital pharmacists. Hosp Pharm. 2003;38(11):1037-46.

43. Duan JJ, Li GC, Situ B, Tao JH, Deng X, Wu JY, et al. Survey of career identity and job satisfaction among young hospital pharmacists in Guangdong province, China. Afr J Pharm Pharmacol. 2011;5(3):386-92.

44. Patrick Hardigan MC. Job satisfaction among practicing pharmacists: a Rasch analysis. Internet J Allied Health Sci Pract. 2007;5:4.

45. Vila LE. The non-monetary benefits of education. Eur J Educ. 2000;35(1):2132.

46. Padiyara RS, Komperda KE. Effect of postgraduate training on job and career satisfaction among health-system pharmacists. Am J Health Syst Pharm. 2010;67(13):1093-100.

47. Lerkiatbundit S. The effects of pharmacy commitment on the development of job satisfaction and organisational commitment. Int J Pharm Pract. 2000; 8(4):260-4.

48. Murawski MM, Payakachat N, Koh-Knox C. Factors affecting job and career satisfaction among community pharmacists: a structural equation modeling approach. J Am Pharm Assoc. 2008;48(5):610-20.

49. Awalom MT, Tesfa AF, Kidane ME, Ghebremedhin MR, Teklesenbet AH Eritrean pharmacists' job satisfaction and their attitude to re-professionalize pharmacy in to pharmaceutical care. Int J Clin Pharm. 2015:37(2):335-41.

50. Al Khalidi D, Wazaify M. Assessment of pharmacists' job satisfaction and job related stress in Amman. Int J Clin Pharm. 2013:35(5):821-8.

51. McCann L, Hughes CM, Adair CG, Cardwell C. Assessing job satisfaction and stress among pharmacists in Northern Ireland. Pharm World Sci. 2009;31(2): 188-94.

52. Schafheutle El, Seston EM, Hassell K. Factors influencing pharmacist performance: a review of the peer-reviewed literature. Health Policy. 2011; 102(2-3):178-92

53. Schommer JC, Pedersen CA, Doucette WR, Gaither CA, Mott DA. Community pharmacists' work activities in the United States during 2000. J Am Pharm Assoc. 2002:42(3):399-406.

54. Kuburovic NB, Dedic V, Djuricic S, Kuburovic V. Determinants of job satisfaction of healthcare professionals in public hospitals in Belgrade, Serbia, cross-sectional analysis. Srp Arh Celok Lek. 2016;144(3-4):165-73.

\section{Publisher's Note}

Springer Nature remains neutral with regard to jurisdictional claims in published maps and institutional affiliations.

Ready to submit your research? Choose BMC and benefit from:

- fast, convenient online submission

- thorough peer review by experienced researchers in your field

- rapid publication on acceptance

- support for research data, including large and complex data types

- gold Open Access which fosters wider collaboration and increased citations

- maximum visibility for your research: over $100 \mathrm{M}$ website views per year

At BMC, research is always in progress.

Learn more biomedcentral.com/submissions 